\title{
Understanding the Relationship Between Tourists' Consumption Behavior and Their Consumption Substitution Willingness Under Unusual Environment
}

This article was published in the following Dove Press journal:

Psychology Research and Behavior Management

\author{
Keheng Xiang ${ }^{1-3}$ \\ Chonghuan $\mathrm{Xu}\left(\mathbb{I D}^{4}\right.$ \\ Jie Wang ${ }^{3}$
}

'China Institute of Regulation Research, Zhejiang University of Finance and Economics, Hangzhou, 310018, People's Republic of China; ${ }^{2}$ School of Hotel and Tourism Management, The Hong Kong Polytechnic University, Kowloon, 999077, Hong Kong, Special Administrative Region of China; ${ }^{3}$ Zhejiang Technical Institute of Economics, Hangzhou, 310018 , People's Republic of China; ${ }^{4}$ School of Business Administration, Zhejiang Gongshang University, Hangzhou, 310018, People's Republic of China
Correspondence: Chonghuan Xu Email talentxch@zjgsu.edu.cn

\begin{abstract}
Introduction: Understanding the relationship between tourists' consumption behavior and their willingness to substitute consumption in unusual environments can promote tourists' sustainable consumption behavior. This study explores the internal relationship between tourists' willingness to engage in sustainable consumption behavior and the substitution of tourism consumption willingness in an unusual environment and the related factors.

Methods: Through qualitative and quantitative mixed research, this study first invited 32 interviewees related to the tourism industry to conduct in-depth and focus group interviews and extracted a research model based on the push-pull theoretical model (PPM) through three rounds of coding of grounded theory. Then, through questionnaire design, pre-release, and formal release, 268 valid questionnaires were collected using a convenience sampling method, and the hypothesis and its mediating effect were verified using a structural equation model.

Results: Further quantitative analysis and verification showed that being in an unusual environment had a positive effect on tourists' perception of crisis awareness, safety risk, and willingness to engage in sustainable consumption behavior. However, the results did not support the unusual environment positively affecting the substitution of tourism consumption willingness, the psychological transformation cost, and the fixed consumption habit negatively affecting the substitution of tourism consumption willingness. In this study, two mediating variables were used to verify the indirect effect of being in an unusual environment and the substitution of tourism consumption willingness. The results showed that the mediating effect was significant.

Conclusion: This study explored an action mechanism model aimed at guiding tourists' willingness for sustainable consumption, based on the environment and consumption behavior, and provided relevant countermeasures for the government and business decisionmakers, enterprises, and investors in the tourism sector.
\end{abstract}

Keywords: unusual environment, grounded theory, PPM theory, sustainable consumption behavior, consumption substitution willingness

\section{Introduction}

Carbon emissions and ecological sustainability in the process of tourism have become a common concern of the international community. The role of tourists in sustainable consumption and the integration of economic development and ecological civilization are both important. Sustainable tourists are green travel tourists 
who consider environmental protection during their travels. At present, the huge increase in consumption has brought great pressure to the human living environment. Tourists' behavior and choice preference in travel are the keys to promoting sustainable ecotourism. Tourist activity includes accommodation, tours, and entertainment, all of which consume a certain amount of energy and contribute to carbon emissions. Furthermore, the potential safety and crisis of tourists during tourism consumption process under unusual environment, to a certain extent, lead to the enhancement of tourists' self-protection consciousness and the formation of negative attitude, which will prompt tourists to have different consumption behavior that may cause the waste of resources. Understanding the relationship between tourists' consumption behavior in an unusual environment and their willingness to substitute consumption may make visitors more willing to engage in sustainable tourism consumption.

This study follows the scientific and normative research procedure, starting with micro psychological variables, constructing a theoretical model, and putting forward a research hypothesis based on pushing, pulling, mooring, and other variable elements and breaks away from the previous decision-making mode of tourists' sustainable consumption behavior and psychology. Thus far, studies have often focused on sustainable tourism behavior, psychological attribution, empirical research, and influencing factors. Research on the intrinsic willingness and effect of tourists' consumption behavior under special circumstances has been neglected, so this research provides facts that rely on planned behavior theory and attitude (behavior) situational theory research paradigm and takes the unusual environment as the situational element. It provides a new research perspective for opening the internal "black box" of the micro psychological decisionmaking of sustainable consumption in the tourism industry. In this study, tourists' sustainable consumption refers to their conscious choice of sustainable and environmentfriendly tourism behavior during travel. From the perspective of connotation, tourists' sustainable consumption includes reducing direct environmental pollution caused by tourism and consciously engaging in responsible tourism. In terms of denotation, sustainable consumption includes the whole continuum of tourist behavior, such as the choice of types of tourism with low energy consumption and low pollution. In this study, a theoretical model was built based on grounded theory and the pushpull theoretical model (PPM), and the internal mechanism of the willingness of tourists in an unusual environment to engage in sustainable consumption behavior and their consumption substitution willingness was studied using mixed quantitative and qualitative research methods.

The main contributions of this paper are summarized as follows:

1. We examined the internal mechanism determining tourists' willingness to engage in sustainable consumption in an unusual environment.

2. We found substitutable behavioral effects and factors that affect tourists and their paths of influence.

3. We explored the micro psychological variables in tourist consumption behavior willingness and introduced tourists' psychological variables and situational environmental variables for the first time, which expands the situational research on empirical analysis of sustainable consumption behavior.

The remainder of this paper is organized as follows. Literature Review provides a literature review. Theoretical Model Construction discusses the research methods and theoretical models. Model Construction and Hypotheses presents the hypotheses. Results of the Analysis and Hypothesis Testing provides the results analysis and hypothesis testing. Finally, Conclusions presents the discussion and conclusions.

\section{Literature Review The Unusual Environment}

In the context of the concept of the unusual environment proposed by Zhang, ${ }^{1}$ the unusual environment refers to an environment outside of people's daily life, study, and work (including both the natural and cultural environments). As Zhang noted, the psychological and behavioral characteristics of tourists in an unusual environment are abnormal. In a related study, Rogers introduced the concept of the usual environment, pointing out that it is often a complex environmental concept that includes geographical boundaries, frequency of access, and the scope of people's daily activities (living, working, studying, etc.) and that the usual environment is a unique situation as a whole, with its own history and significance, which is to some extent a function of geographical distance. ${ }^{2}$ De San Eugenio Vela et al proposed that the usual environment represents a space or place and that space is an abstract physical concept; they also examined individual details, such as the 
visiting frequency of attractors (for calculating distance) and the perception of the usual environment through a super-large sample survey. ${ }^{3}$

In academic studies, the dimensions of the current environmental situation are usually understood to include economic, information, cultural, cognitive, and economic dimensions. ${ }^{4,11}$ Belk proposed that being in an unusual environment means to encounter strangeness and feeling unsafe, leading tourists, in general, to try to overcome the psychological distance to their usual environment by making more efforts to reduce strangeness, which also takes into consideration behavioral sunk costs. ${ }^{5}$ McKercher pointed out from the perspective of physical distance that the sunk cost contained in the unusual environment more or less affected tourists' choice of destination and their consumption there. ${ }^{6}$ Research on the information dimension of an unusual environment focuses on issues such as chaos and asymmetric information; for example, Beales et al suggested that in an unusual environment, a lack of understanding of the price and quality of goods could easily lure visitors to tourist traps. ${ }^{7}$ Gursoy noted that tourists rely on second-hand information channels more than they would in their usual environment, thus leading to chaos, information overload, and fuzzy information. ${ }^{8} \mathrm{Lu}$ found that tourists' information search and filtering costs are higher in the non-habitual environment. ${ }^{9}$ Regarding the cultural dimension, there is a higher incidence of cultural conflict than in the usual environment. Crompton noted that cultural distance caused discomfort, conflict, and discrimination in an unusual environment and investigated the source of cultural distance between the usual routine environment and that of the tourist destination. ${ }^{10}$ Ye also proposed that cultural distance acts as a buffer in crosscultural communication between hosts and guests, reducing conflict between them and concluded that cultural differences between habitual and unusual environments are important representations of the tourism activity space. ${ }^{12}$ In terms of the cognitive dimension of an unusual environment, researchers have mainly focused on environmental perception and cognition, including risk safety, familiarity, and strangeness. For example, Cohen mentioned in as early as 1972 that tourists sought both familiarity and strangeness in the process of social contact with host countries. ${ }^{13}$ To give another example, Mitchell and Greatorex proposed that the unusual environment accompanied by strangeness would increase tourists' risk perception, while the environment cover could reduce such perception. ${ }^{14}$ As for the empirical analysis of the unusual environment, Chen proposed that usual and unusual environments have the function of switching and projecting, with two combined effects of active passivity and positive passivity, which will generate the perception of insecurity and discomfort. The experience of tourism is a combination of the time and space of tourists' (non) unusual environment and (non) leisure time. ${ }^{15}$ Hares et al pointed out that tourists have barriers to sustainable consumption in unusual environments, so they seldom pay attention to environmental impacts or interests in their tourism decision-making. ${ }^{16}$ In an unusual environment, because their identity is unknown, the moral constraints of tourists are relaxed, their self-discipline is lower, and behavior that do not occur in the habitual environment occur easily.

In summary, information chaos and cultural conflict in an unusual environment will lead to confusion in tourists' cognition and a decrease in their sense of experience, psychological strangeness and sense of crisis and the corresponding psychological adjustments and behavioral decisions to respond to the surrounding tourism environment. Therefore, the theoretical model constructed in this study is based on the relevant research on the information and cognitive dimensions in an unusual environment, deepening and expanding the empirical analysis of tourists' consumption behavior and willingness to substitute consumption.

\section{Sustainable Consumption Behavior}

In terms of the mechanism model of sustainable consumption willingness, research has typically focused on overload tourism in Europe, and studies on the mechanism and countermeasures for sustainable tourism saturation have been from the perspectives of policy, organization, institution, and behavior. ${ }^{17}$ There have also been studies on models of relevant decision-making mechanisms to promote the implementation of sustainable consciousness by identifying potential factors in sustainable tourism, ${ }^{18}$ such as determining the driving factors in specific tourism environments to formulate rules for the precision and standardization of sustainable tourism for tourists. Since the role of architecture is often neglected in research on sustainable tourism, to achieve the promotion and penetration of sustainable tourism, the internal mechanism architecture of tourists and the environment should be changed. ${ }^{19}$ In general, the current sustainable tourism consumption mechanism model carries out relevant research by examining the internal potential factors in attitude and 
behavior from an objective perspective and how it can be applied in practice.

In recent years, studies of the factors influencing sustainable consumption willingness have focused on consumer behavior and cognition, such as Lao, ${ }^{20}$ who concluded that consumers' innovation consciousness has a significant impact on sustainable consumption intention. Lu et al found that consumers' personality characteristics have a significant impact on their moral beliefs and that some dimensions of consumers' moral beliefs have a significant predictive effect on their willingness to buy sustainable products. $^{21}$ Pinto et al examined how the salience of personal and social identity changes the relationship between sustainable consumption and intention types. ${ }^{22}$ The results show that when personal identity is significant, the intention to transcend the self has more influence on sustainable consumption than the intention to promote one's self-interest. When social identity is significant, the influence of intention to transcend the self and promote one's selfinterest in sustainable consumption are similar. Nguyen et al theoretically developed and tested two key regulators of the relationship between sustainable consumption intentions and behavior from the perspective of consumer behavior, that is, the availability of sustainable products and personal consumption expenditure (PCE). ${ }^{23}$

\section{Substitution of Tourism Consumption Willingness}

There are many forms of consumption substitution. This study focuses on consumption substitution, that is, alternative consumption or consumer behavior, when choosing substitutes. In an unusual environment, tourists' perception of safety risks will be enhanced, and the sense of insecurity and strangeness will prompt them to choose other forms of tourism to replace the original type of tourism or to engage in alternative tourism behavior. Consumption substitution in this study is based on the concept of substitution in Porter's five forces model, ${ }^{24}$ which holds that substitution is the process by which one product or service replaces another to achieve certain needs for the buyer and that substitution analysis is equally applicable to products and processes. The object of substitution here usually refers to the category (category substitution), and the substitution originally referred to by Porter is concerned with consumer products. This study extends Porter's concept of substitutes by examining the transformation of the mode of consumption (consumption substitution behavior). As few studies have considered the issue of consumption substitution, this study examines consumption substitution behavior in the process of participating in tourism activity. This type of tourism substitution behavior is the result of tourists' attention and awareness of environmental protection. It is one of the behavioral results of promoting tourists' green consumption and it can transform tourists' intention of green consumption behavior into a process of consumption substitution.

Previous studies that have examined similar issues include an examination of the migration of purchase channels by Reinartz et $\mathrm{al}^{25}$ and a paper by Ratneshwar et $\mathrm{al}^{26}$ on how to provide consumers with alternative product platforms and to offer a comparison standard for products in alternative schemes. Consumption substitution is generally a transformation of long-term trends, usually occurring at an industry level. This study examines the corresponding consumption mode and behavior substitution.

\section{The Push-Pull Theoretical Model (PPM)}

The PPM model (pull, push, and mooring) began with the study of the earliest migration behavior. Heberle summarized the structure and spatial distribution of population migration mechanisms, which gave rise to the initial push-pull theory of population migration. ${ }^{27}$ Moon found further factors in migration theory, such as those that encourage people to leave their original habitats, for example, if their former residence had a negative effect on their lives. ${ }^{28}$ Some scholars believe that the PPM model is also an effective approach for analyzing the relationship between consumer motivation and behavior. Therefore, it has been introduced to the field and the factors that influence consumer behavior are studied around the three factors "push", "pull" and "mooring".

For example, Goossens studied the motivation of tourists and their emotion-oriented destination selection decisions using the PPM model and proposed that tourists are driven by their emotional needs and interests. ${ }^{29}$ In recent years, scholars have turned to the PPM model more frequently to study tourism consumers. For example, Kim et al examined the push and pull factors that increase visitors to South Korea's national parks. ${ }^{30}$ The results of their factor analysis showed that there were four push factors: appreciating nature as a family, escaping the obligations of daily life, engaging in exploration, and establishing a friendship. The three pull factors were the core tourism resources: information, facility convenience, and transportation/accessibility. In another 
study, Klenosky used the means-ends theory to examine the relationship between driving and pulling factors that motivate and guide travel behavior. ${ }^{31}$ Jung et al tested the conversion adaptation behavior of PPM in tourists' choice of airlines and concluded that PPM is directly related to tourists' willingness to change airlines. ${ }^{32}$ Poor service, opaque prices, low levels of customer satisfaction, and weak trust push tourists away from existing airlines. The attraction of alternative options, opportunities, and price concessions can motivate tourists to choose new routes, while other factors such as high alternative costs, limited choice trends, and low priority alternative costs, have anchoring effects.

\section{Theoretical Model Construction Overall Design}

This study designed a qualitative and quantitative research based on the literature review of the above three important variables and in conjunction with the theoretical model of PPM. It attempted to find explanatory variables through a qualitative analysis, constructed a theoretical framework for the PPM, and then verified the framework through a quantitative analysis.

There are no definite categories, scales, or related theoretical assumptions available for studying sustainable consumption behavior patterns. In a preliminary investigation and interviews, many respondents pointed out the lack of clear boundaries and connotations of sustainable consumption behavior, especially sustainable consumption in travel, as everyone had a different understanding of the issues involved. It was obvious that this could give rise to misunderstandings if a structured questionnaire were to be administered without taking this into account. As this could affect the sample of the quantitative research directly, as well as the reliability and validity of the results, a mixed research method was adopted in the present study. A qualitative research method was first used to establish a theoretical framework and was then combined with variable detection and qualitative research results, which were proposed and verified using a quantitative research method.

This study first used a semi-structured interview, a qualitative approach, and sampling theory to select the interview objectives. Based on grounded theory, an exploratory study was conducted to collect verbatim transcripts of interviews from a representative sample of the public. Through open coding, spindle coding, and selective coding of the verbatim transcripts using the MAXQDA2018 software package, a correlation model, and the influencing factor theory of tourists' willingness to engage in sustainable consumption and substitutive behavior were constructed. In the process of analyzing verbatim manuscripts, a continuous comparative analysis was adopted to refine and revise the theories continuously until the theories and concepts were saturated. The concepts were verified with the variables after sorting out the theories. After verification, the related variables were measured for concept, model hypothesis, and model validation.

\section{Category Extraction and Theoretical Model Construction}

A total of 32 invited tourism industry experts, scholars, and professionals (middle-aged and young teachers) participated in the survey. A combination of individual indepth interviews and focus group interviews was used. Overall, there were 16 one-on-one interviews (each 30 to 45 minutes) and 4 focus group interviews with an average of 4 people in each group (each about 1 hour 30 minutes). Participants provided consent before participating in this research and to record the interviews. The interviews were transcribed using a recording software, and the total length of the interview transcripts was 180,000 words. This study randomly selected two-thirds of the interviews for consistency, using the theoretical concepts of the saturation test and trend chart. In open coding category extraction, only concepts that were repeated more than thrice in setting the initial concepts were selected, while less frequently occurring concepts were eliminated. Table 1 shows part of the initial concepts and categories. Owing to a space problem, for each of the initial categories, only the raw data of the three original materials and the corresponding initial concepts were selected. The main axis coding mined and extracted potential logical relations between categories. Table 2 shows the open coding categories. This study classifies different categories according to their conceptual interrelations and logical relations and summarizes eight main categories. The typical relational structures of the main categories in this study are listed in Table 3.

This study identified the core category of sustainable consumption behavior and the consumption substitution willingness. The storyline around the core category can be summarized as an unusual environment, sustainable consumption behavior psychological costs, and fixed consumption. The study used the PPM theoretical model to identify the thrust factors (push) that can promote sustainable consumption behavior. Pull factors for sustainable consumption behavior include urging tourists to choose alternative tourism 
Table I Initial Concepts and Categories

\begin{tabular}{|c|c|}
\hline Category & Original Statement (Initial Concept) \\
\hline \multirow[t]{2}{*}{$\begin{array}{l}\text { Environmental problem } \\
\text { identification }\end{array}$} & $\begin{array}{l}\text { W05 I sometimes feel insecure during the journey. The design of some of the scenic spots is not reasonable. It has } \\
\text { a great impact on the ecological environment (environmental crisis awareness). }\end{array}$ \\
\hline & W06 I can judge the serious consequences that may occur in my travel environment (pre-identification). \\
\hline \multirow[t]{2}{*}{$\begin{array}{l}\text { Awareness of environmental } \\
\text { issues }\end{array}$} & $\begin{array}{l}\text { W08 I always think that resources are inexhaustible and abundant, so I do not think about it so much (weak sense } \\
\text { of crisis). }\end{array}$ \\
\hline & W05 Sometimes I think the tourism environment I am in needs to be improved (perception decision). \\
\hline \multirow[t]{2}{*}{ Environmental impact } & W05 Sometimes the tourist environment will make my mood remain continuously low (emotional impact). \\
\hline & $\begin{array}{l}\text { W09 I am not able to control my emotions and state of mind in a strange environment (controlling influencing } \\
\text { factors). }\end{array}$ \\
\hline \multirow[t]{2}{*}{$\begin{array}{l}\text { Knowledge of sustainable } \\
\text { consumption }\end{array}$} & $\begin{array}{l}\text { W09 Talk to today's young people about sustainable consumption? I do not know how to express it in detail } \\
\text { (knowledge propaganda). }\end{array}$ \\
\hline & $\begin{array}{l}\text { W03 Sustainable consumption covers a wide range, including daily consumption, virtual consumption, etc. so it is } \\
\text { difficult to categorize and sort it out (knowledge sorting). }\end{array}$ \\
\hline \multirow[t]{2}{*}{$\begin{array}{l}\text { Sustainable consumption } \\
\text { values }\end{array}$} & $\begin{array}{l}\text { W04 Sustainable consumption means the sustainable development and sustainable protection of the ecological } \\
\text { environment (values). }\end{array}$ \\
\hline & $\begin{array}{l}\text { W08 I do not buy non-ecological souvenirs and do not visit non-sustainable tourism destinations during a trip } \\
\text { (values). }\end{array}$ \\
\hline \multirow[t]{2}{*}{ Crisis identification } & $\begin{array}{l}\text { WII Sometimes I check weather and geological forecasts for the destination in advance (travel crisis } \\
\text { identification). }\end{array}$ \\
\hline & $\begin{array}{l}\text { WIO Sometimes I can tell if there is a need to continue traveling by the weather forecast (travel crisis } \\
\text { identification). }\end{array}$ \\
\hline \multirow[t]{2}{*}{ Crisis value } & W09 Is there nothing more important than life? Self-protection first (values). \\
\hline & W07 No matter how beautiful the scenery is, it is not as safe as living at home (values). \\
\hline \multirow[t]{2}{*}{ Mindset } & W06 I have a hard time accepting new ideas or specific ideas (thinking impedance). \\
\hline & W0I3 I do not want to make travel decisions (thinking impedance). \\
\hline
\end{tabular}

consumption types include a sense of risk to safety and crisis cognition. The psychological transformation cost and consumption habits of tourists have an anchoring effect (mooring) in this model, which will hinder the formation of tourists' willingness to consume instead of traveling. Therefore, the theoretical model developed in this study is consistent with the PPM model. A specific theoretical model based on PPM is shown in Figure 1. To test the saturation of theories and concepts, one-third of the interview records were used for the theoretical saturation test. Neither new categories and relationships nor new factors in the five main categories were found. Figure 2 shows the trend consistency chart of categories. The number of new categories shows a linear trend distribution and the number of new categories of interviewees from P9 to P16 is greatly reduced, indicating that the categories of interviewees have obvious internal consistency. The above theoretical model based can thus be considered theoretically saturated.

\section{Model Construction and Hypotheses}

\section{Measurement and Analysis of Variables} Push Factors

The usual environment: Based on Ajzen's theory of planned behavior (TPB), ${ }^{33,34}$ individual environmental behavioral willingness is considered the first psychological variable. In this study, the concept of the usual environment is understood in a manner similar to that proposed by Gursoy et $\mathrm{al}^{8}$ and Crompton, ${ }^{10}$ with an emphasis on the information dimension and the related characteristics of the cultural dimension, that is, 
Table 2 Categorization of Open Coding

\begin{tabular}{|c|c|c|}
\hline Main Categories & $\begin{array}{l}\text { Corresponding } \\
\text { Category }\end{array}$ & Connotation of the Relationship \\
\hline Unusual Environment & Environmental recognition & $\begin{array}{l}\text { The respondents are able to identify the status of the environment in an unusual } \\
\text { environment. }\end{array}$ \\
\hline \multirow[t]{3}{*}{$\begin{array}{l}\text { Sustainable consumption } \\
\text { behavior }\end{array}$} & $\begin{array}{l}\text { Knowledge of sustainable } \\
\text { consumption }\end{array}$ & $\begin{array}{l}\text { The unclear knowledge of sustainable consumption is related to the intention of } \\
\text { sustainable consumption behavior. }\end{array}$ \\
\hline & $\begin{array}{l}\text { Sustainable consumption } \\
\text { attitude }\end{array}$ & $\begin{array}{l}\text { The attitude of sustainable consumption is related to the willingness of sustainable } \\
\text { consumption behavior. }\end{array}$ \\
\hline & $\begin{array}{l}\text { Sustainable consumption } \\
\text { values }\end{array}$ & $\begin{array}{l}\text { The holding of sustainable consumption values can promote the willingness of } \\
\text { sustainable consumption behavior. }\end{array}$ \\
\hline $\begin{array}{l}\text { Crisis and security risk } \\
\text { perception }\end{array}$ & Security risk identification & The interviewees have good security risk identification ability. \\
\hline \multirow{2}{*}{$\begin{array}{l}\text { Psychological costs and fixed } \\
\text { consumption }\end{array}$} & Mindset & Mindset is a state in the process of psychological cost estimation. \\
\hline & Spending habits & Respondents have fixed spending habits while traveling. \\
\hline
\end{tabular}

Table 3 Typical Relational Structure of the Main Categories

\begin{tabular}{|c|c|c|}
\hline Relational Structure & $\begin{array}{l}\text { Model } \\
\text { Element } \\
\text { Extraction }\end{array}$ & Connotation of Relationship Structure \\
\hline Unusual environment willingness & PPM & $\begin{array}{l}\text { Unusual environment is the external driving factor (external factor) that prompts } \\
\text { tourists to produce behavioral intention, which determines tourists' willingness to } \\
\text { produce a type of consumption behavior. }\end{array}$ \\
\hline Unusual environment & \multirow[t]{2}{*}{ Push } & \multirow{2}{*}{$\begin{array}{l}\text { The identification, cognition, and influence of environmental problems in non-habitual } \\
\text { environments are related to the behavioral intention of sustainable consumption, which } \\
\text { affects tourists during their travels willingness to act sustainable. }\end{array}$} \\
\hline Sustainable consumption behavior & & \\
\hline Unusual environment & \multirow[t]{3}{*}{ Push } & \multirow{3}{*}{$\begin{array}{l}\text { In the non-usual environment, tourists can judge the related impact of environmental } \\
\text { problems by themselves, which will generate the willingness of consumption to replace } \\
\text { tourism. }\end{array}$} \\
\hline $\begin{array}{l}\text { Willingness for tourism } \\
\text { consumption substitution }\end{array}$ & & \\
\hline Cognition-willingness & & \\
\hline $\begin{array}{l}\text { Psychological transformation costs } \\
\text { and fixed consumption }\end{array}$ & Moor & $\begin{array}{l}\text { The psychological transformation cost and fixed consumption habit of tourists in tourism } \\
\text { can affect tourists' willingness to replace tourism. }\end{array}$ \\
\hline
\end{tabular}

that in unusual circumstances, a situation of information asymmetry and chaos occurs, with conflicts resulting from cultural distance and discomfort. Therefore, based on the environmental behavior scale proposed by Stern and the four dimensions identified in the literature review (economy, information, culture, and cognition), seven question options were set.

\section{Pull Factors}

Sustainable consumption behavior: Stern et al argued that tourists' sustainable consumption behavior was affected by environmental values and social norms, combining the attitude - behavior - situational theory with a focus on the individual environmental behavior associated with external situation factors. ${ }^{35}$ Recently, many scholars have studied and analyzed the situational factors that affect behavior, as the paper by Stern et al, who proposed that environment and policy support can influence consumer behavior. ${ }^{36}$ Therefore, with reference to the environmental behavior scale proposed by Stern et al and the appropriate modification of Ajzen's theory of planned behavior scale, eight sustainable consumption behavior 


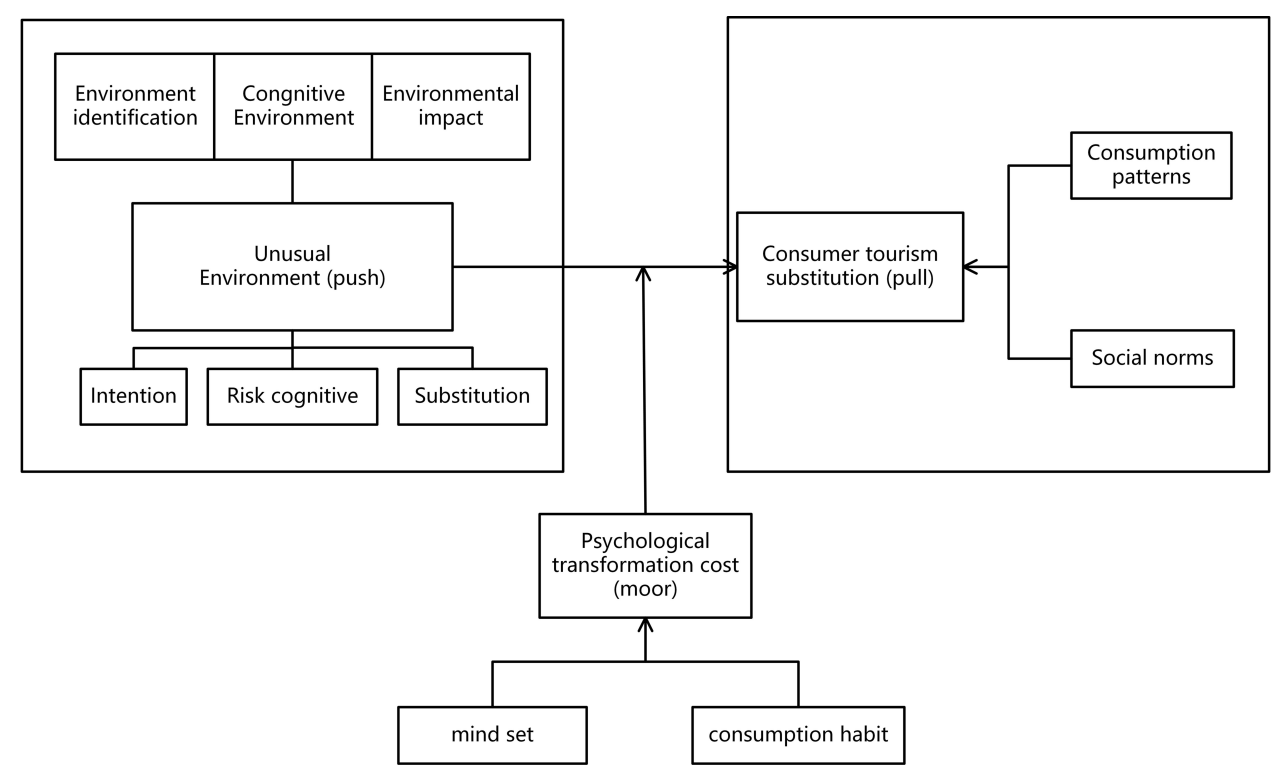

Figure I This study is based on the theoretical model of PPM.

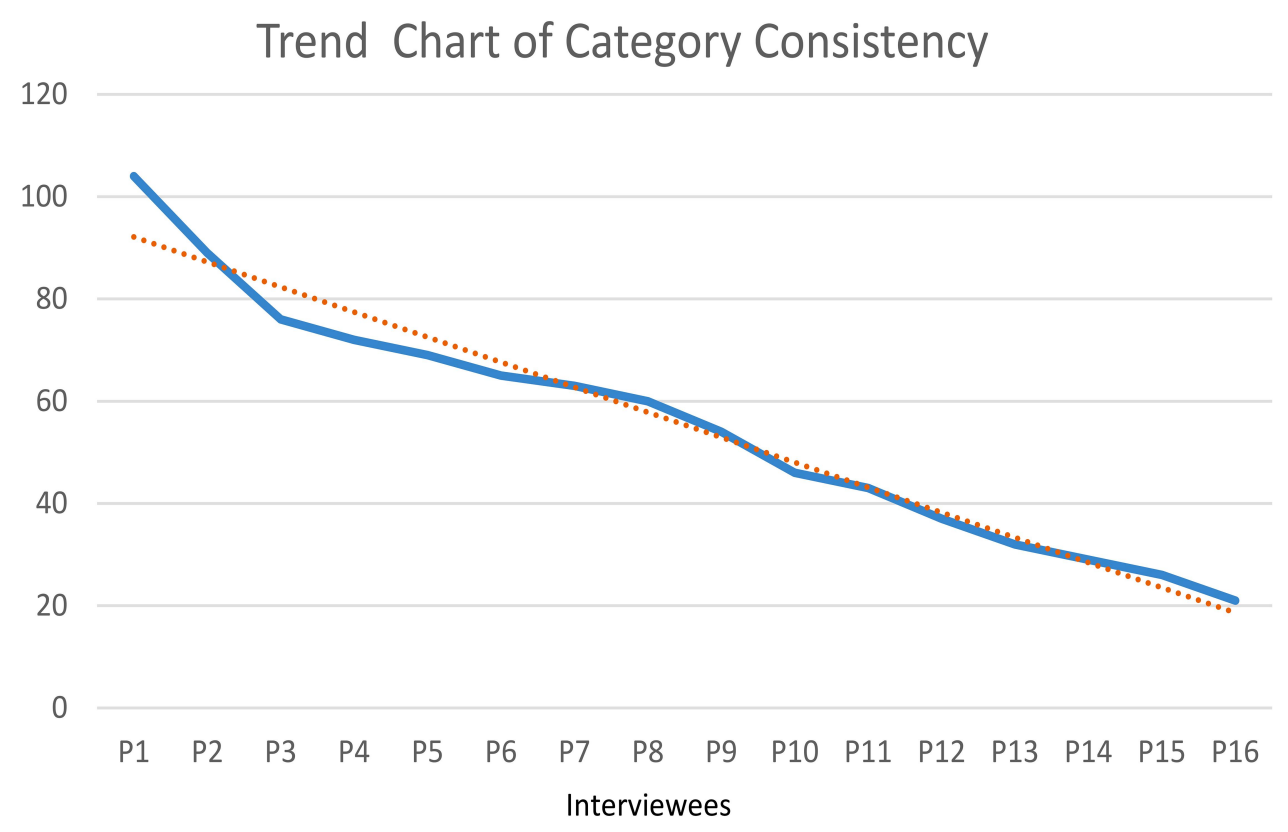

Figure 2 Trend chart of category consistency.

measurement questions were designed based on the perspectives of housing, travel, tourism, shopping, and entertainment.

The willingness of tourism consumption substitution: Consumption substitution in this study is the concept of total substitution in Porter's five-force model. ${ }^{24}$ With reference to the new environmental paradigm (NEP) scale developed by Dunlap and combined with the results of the existing literature review, six options (mainly situational measurement items for consumption to replace tourism behavioral intentions) were designed.

Crisis and safety risk perception: based on the NEP scale developed by Dunlap et al and the results of the existing literature review, seven options for crisis and risk safety perception were designed (mainly for the perception and judgment of non-sustainable tourism). ${ }^{37}$ 


\section{Anchoring Factors}

Psychological transformation costs and fixed consumption: Conversion costs are faced in the conversion of one-time costs. $^{38,39}$ Related studies have shown that conversion costs are important factors in the process of consumers' offline to online channel migration. Therefore, because of the cost of the transformation of psychological perception, the migration behavior of tourists may be suppressed. ${ }^{40,41}$ With reference to Dunlap's NEP scale and combined with the findings of existing literature, six items of psychological transformation cost and fixed consumption were designed (mainly measuring the anchoring effect of benefit perception).

\section{Research Model and Research Hypothesis}

Using grounded theory and the PPM as this study's theory correlation model, the usual role is the thrust of the unusual environment variables; positive roles are crisis and security risk perception, sustainable consumption behavior, and the willingness to substitute tourism consumption. ${ }^{38,42}$ As variables of pull forces, crisis and security risk perception have a positive influence on sustainable consumer behavior. ${ }^{43-47}$ Psychological transformation costs and fixed consumption have a negative impact on the substitution of willingness to consume tourism. ${ }^{48,49}$ To ensure the accuracy of the model and hypothesis construction, two mediating variables were introduced into this study: crisis and safety risk perception and sustainable consumption behavior. It is assumed that these two variables play a mediating role in influencing consumption substitution willingness in an unusual environment. The research hypotheses are presented in Table 4.
The research model of this study was constructed through the above theoretical analysis and research hypotheses, as shown in Figure 3.

\section{Questionnaire Design and Descriptive Statistics}

This study randomly recruited 15 ordinary tourists to conduct focus group discussions on the outcome and impact variables and invited 6 professors from the academic tourism studies field and 3 experts from the tourism industry to analyze the contents and questions of the focus group discussions. The results of the discussions of the tourists, academic professors, and experts were fully summarized and refined. The relevant outcome and influence variables were selected, which confirmed the results of the literature review. On this basis, this study designed the initial questionnaire, which was distributed by researchers in the field of tourism as part of the pre-test. The questionnaire's content structure and topics were inspected and evaluated using the SPSS 24.0 software reliability test data and deleted if they did not conform to the standard question based on the results of the test. Moreover, part of the subject expressions was also adjusted in the multi-item colloquial correction and in the green tourism consumption concepts; further, notes were added to the scene and concept descriptions.

Considering that hotel accommodation is an obligatory choice for overnight tourists in an unusual environment and their consumption behavioral willingness is more representative, overnight tourists traveling in Hangzhou were selected as the objects of the survey. The convenience sampling method was adopted to represent the front desk of H\&H Hotels among mainstream budget hotels. The front desk service staff

Table 4 Hypothesis of This Study

\begin{tabular}{|c|c|}
\hline HY & Content \\
\hline $\mathrm{HI}$ & Being in an unusual environment positively affects the crisis and risk perception \\
\hline $\mathrm{H} 2$ & Being in an unusual environment positively affects sustainable consumption behavior \\
\hline $\mathrm{H3}$ & Being in an unusual environment positively affects the substitution of tourism consumption willingness \\
\hline H4 & The crisis and risk perception positively affects the substitution of tourism consumption willingness \\
\hline H5 & The sustainable consumption behavior positively affects the substitution of tourism consumption willingness \\
\hline H6 & The psychological transformation costs and the fixed consumption negatively affect the substitution of tourism consumption willingness \\
\hline H7 & $\begin{array}{l}\text { The crisis and risk perception plays a mediating role in the influence of an unusual environment on substitution of tourism consumption } \\
\text { willingness }\end{array}$ \\
\hline H8 & $\begin{array}{l}\text { Sustainable consumption behavior plays a mediating role in the influence of an unusual environment on substitution of tourism consumption } \\
\text { willingness }\end{array}$ \\
\hline
\end{tabular}




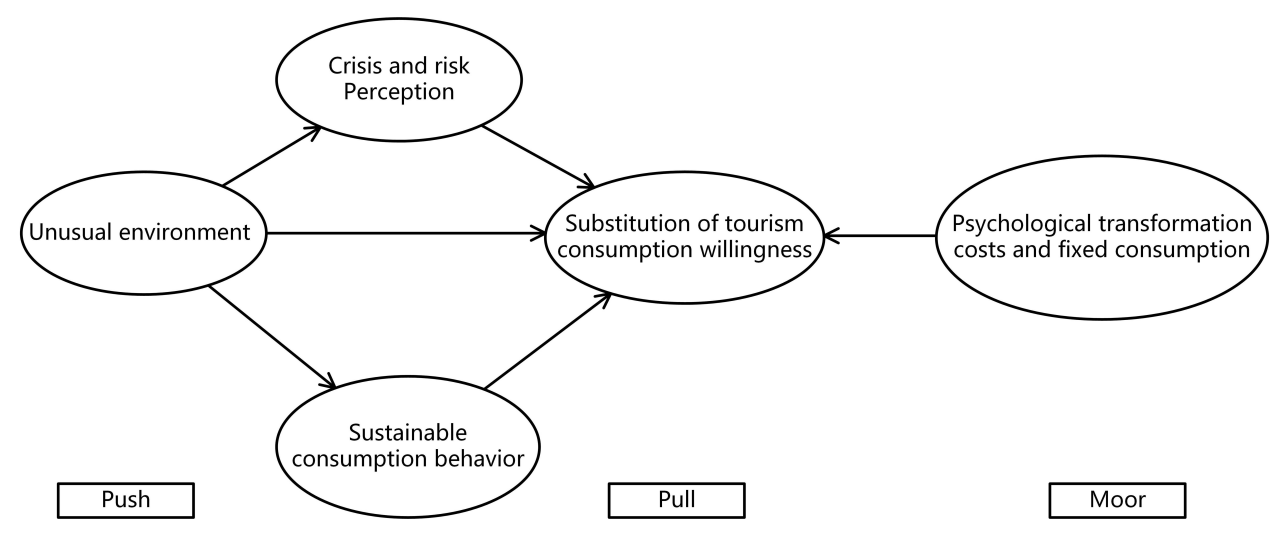

Figure 3 Research model.

cooperated with the sharing of a questionnaire link for tourists to fill in and submit on their mobile phones.

From July 15, 2019, to July 20, 2019, five members of this group in Hangzhou, China, gathered a total of 280 questionnaires. After deleting incomplete samples, there remained 268 valid questionnaires, which gave an effective response rate of $95.7 \%$. The sample ratio was roughly 51.6:48.4 and the age group best represented was between 25 and 45 years $(64.8 \%)$, the level of education was bachelor's degree holders $(67.8 \%)$, and the monthly income bracket was RMB 5500-8000 (56.7\%). The sample thus conformed to the next-stage characteristics of travel tourist properties. The variable descriptions and statistical descriptions are presented in Table 5.

According to the different use purposes, a confirmatory factor analysis (CFA) was performed to verify the theoretical model, that is, to test the ability of the model to fit the actual data with pre-defined factors. First, an exploratory factor analysis was carried out on the behavioral variables and then the measurement model was tested through CFA to ensure the reliability and validity of the model. Finally, the SEM model was used to verify the research hypothesis and the bootstrap method was used to test the indirect effect sizes of the two mediation routes to ensure the effectiveness of the mediation variable test.

\section{Results of the Analysis and Hypothesis Testing} Testing the Measurement Model

To measure the reliability and validity, a CFA was performed on the measurement model. CFA is a research method that determines whether the correspondence between measurement factors and measurement items (scale items) is consistent with the predictions of the researchers. Its main purpose is to analyze the validity of convergence and to verify the measurement items belonging to the same factor at the time of measurement. In this study, AVE (average variance extracted) and CR (composite reliability) were combined for analysis. If the AVE of each factor is greater than 0.5 and the $C R$ value is greater than 0.7 , it indicates good polymerization validity. Simultaneously, this study checked whether the factor load coefficient corresponding to each measurement item was greater than 0.7 .

In general, the factor load of the CFA analysis was between 0.5 and 0.95 , indicating that the model has good adaptability. Table 6 lists the factor loads of all the variables. All factor loads from Y1 to X28 were between 0.5 and 0.95 , so all the questions were retained. The combined reliability was greater than 0.5 and the mean variation extraction was greater than 0.5 . The combination reliability of all the potential variables was above 0.7 , indicating that the internal consistency of each variable was good. The AVE of all the variables exceeded the minimum value of 0.5 and the correlation coefficient between all the variables was less than the square root of the AVE (Table 7), indicating that the measurement model had good aggregation and discriminant validity.

\section{Analysis of the Structural Model Results}

Figure 4 shows the influence path of the structure model and its normalized path coefficient, and Table 8 lists the results of hypothesis testing. The unusual environment had a significant positive impact on tourists' perception of crisis and safety risk (score $=0.392, \mathrm{t}=4.4, \mathrm{p}<0.001$ ) and on their sustainable consumption behavior (score $=$ $0.243, \mathrm{t}=3.0, \mathrm{p}<0.001)$ but no significant impact on substitution of tourism consumption willingness $(\mathrm{p}>0.5)$. 
Table 5 Variable and Statistical Description

\begin{tabular}{|c|c|c|c|c|c|c|c|}
\hline \multicolumn{2}{|c|}{ Variables } & \multirow{2}{*}{$\begin{array}{l}\text { Predictor Variables } \\
\text { YI I will choose green tourism to } \\
\text { replace my existing unsustainable } \\
\text { tourism behavior }\end{array}$} & \multirow{2}{*}{$\begin{array}{l}\text { Variable Definitions } \\
\text { A Likert scale was used, with } I-5 \text { representing the } \\
\text { enhancement of behavior and willingness. ( } I= \\
\text { strongly disagree, } 3=\text { strongly agree, } 5=\text { strongly } \\
\text { agree) }\end{array}$} & \multirow{2}{*}{$\begin{array}{l}\text { The } \\
\text { Mean }\end{array}$} & \multirow{2}{*}{$\begin{array}{l}\text { Standard } \\
\text { Deviation }\end{array}$} & \multirow{2}{*}{$\begin{array}{l}\text { Partial } \\
\text { Degrees }\end{array}$} & \multirow{2}{*}{$\begin{array}{c}\text { Kurtosis } \\
-0.304\end{array}$} \\
\hline $\begin{array}{l}\text { The } \\
\text { results } \\
\text { of }\end{array}$ & $\begin{array}{l}\text { Substitution of } \\
\text { tourism } \\
\text { consumption }\end{array}$ & & & & & & \\
\hline & & $\begin{array}{l}\text { Y2 I will choose safe and } \\
\text { environmentally friendly green } \\
\text { tourism to replace my current } \\
\text { tourism behavior }\end{array}$ & & 3.71 & 0.91 & -0.254 & -0.141 \\
\hline & & $\begin{array}{l}\text { Y3 I would like to reduce some of } \\
\text { my unsustainable travel behavior of } \\
\text { thrills and adventures }\end{array}$ & & 3.74 & 1.03 & -0.468 & -0.317 \\
\hline & & $\begin{array}{l}\text { Y4 I can identify which behavior are } \\
\text { green tourism and find alternatives }\end{array}$ & & 3.37 & 1.05 & -0.061 & -0.658 \\
\hline & & $\begin{array}{l}\text { Y5 It is everyone's social } \\
\text { responsibility to replace tourism } \\
\text { behavior with green consumption }\end{array}$ & & 3.73 & 0.91 & -0.402 & -0.035 \\
\hline & & $\begin{array}{l}\text { Y6 I will use green consumer } \\
\text { products and services instead of my } \\
\text { original unsustainable tourism } \\
\text { behavior }\end{array}$ & & 3.71 & 0.90 & -0.4 & 0.25 \\
\hline \multirow{15}{*}{$\begin{array}{l}\text { Affect } \\
\text { the } \\
\text { variable }\end{array}$} & \multirow{8}{*}{$\begin{array}{l}\text { Sustainable } \\
\text { consumption } \\
\text { behavior }\end{array}$} & $\begin{array}{l}\text { XI I do not actively use disposable } \\
\text { items }\end{array}$ & & 3.46 & 1.13 & -0.268 & -0.668 \\
\hline & & $\begin{array}{l}X 2 \text { I economize with the use of } \\
\text { unsustainable travel resources }\end{array}$ & & 4.00 & 1.03 & -1.022 & 0.836 \\
\hline & & $\mathrm{X} 3$ I reduce unnecessary waste & & 4.39 & 0.92 & -1.788 & 3.326 \\
\hline & & $\begin{array}{l}\text { X I use public transportation in } \\
\text { tourist areas }\end{array}$ & & 4.09 & 0.95 & -1.15 & 1.366 \\
\hline & & $\begin{array}{l}\text { X5 I do not buy over-packaged } \\
\text { souvenirs }\end{array}$ & & 3.99 & 0.99 & -0.692 & -0.16 \\
\hline & & X6 I choose green hotels & & 3.89 & 0.90 & -0.514 & -0.076 \\
\hline & & $\begin{array}{l}\text { X7 I select green tourism activities } \\
\text { with low energy consumption }\end{array}$ & & 3.83 & 0.97 & -0.579 & -0.005 \\
\hline & & $\begin{array}{l}\text { X8 I actively promote green } \\
\text { tourism behavior and concepts to } \\
\text { fellow travelers }\end{array}$ & & 3.70 & 1.09 & -0.582 & -0.28 \\
\hline & \multirow{7}{*}{$\begin{array}{l}\text { Unusual } \\
\text { environment }\end{array}$} & X9 I feel insecure & & 3.28 & 1.17 & -0.178 & -0.745 \\
\hline & & XI0 I feel confused & & 3.21 & 1.18 & -0.147 & -0.911 \\
\hline & & XII I feel a culture clash & & 3.01 & 1.06 & -0.02 & -0.56 \\
\hline & & $\begin{array}{l}X 12 \text { My travel experience is } \\
\text { decreasing }\end{array}$ & & 2.82 & 1.17 & 0.196 & -0.899 \\
\hline & & $\begin{array}{l}X \mid 3 \text { I think the environment is very } \\
\text { strange }\end{array}$ & & 3.34 & 1.11 & -0.273 & -0.549 \\
\hline & & XI4 I have a sense of crisis & & 2.86 & 1.18 & 0.079 & -0.941 \\
\hline & & $\begin{array}{l}\text { XI5 I want to travel in a different } \\
\text { way }\end{array}$ & & 2.83 & 1.22 & 0.28 & -0.904 \\
\hline
\end{tabular}

(Continued) 
Table 5 (Continued).

\begin{tabular}{|c|c|c|c|c|c|c|}
\hline Variables & Predictor Variables & Variable Definitions & The & Standard & Partial & Kurtosis \\
\hline \multirow[t]{7}{*}{$\begin{array}{l}\text { Crisis and security } \\
\text { risk perception }\end{array}$} & $\begin{array}{l}\mathrm{X} 16 \mathrm{~A} \text { lot of travel is not green } \\
\text { these days }\end{array}$ & & 3.45 & 0.97 & -0.398 & -0.044 \\
\hline & $\begin{array}{l}\text { XI7 Non-green tourism will } \\
\text { accelerate the global greenhouse } \\
\text { effect }\end{array}$ & & 3.72 & 1.03 & -0.565 & -0.142 \\
\hline & $\begin{array}{l}\text { XI8 Non-green travel is an unsafe } \\
\text { type of travel }\end{array}$ & & 3.07 & 1.16 & 0.009 & -0.897 \\
\hline & $\begin{array}{l}\mathrm{X} 19 \text { Mankind is facing serious } \\
\text { environmental problems }\end{array}$ & & 4.05 & 1.00 & -0.843 & 0.139 \\
\hline & $\begin{array}{l}\text { X20 The deterioration of the } \\
\text { ecological environment is worrying }\end{array}$ & & 4.06 & 0.97 & -1.037 & 1.039 \\
\hline & $\begin{array}{l}\text { X2I Many travel destinations are } \\
\text { currently not sustainable }\end{array}$ & & 3.79 & 1.00 & -0.465 & -0.445 \\
\hline & $\begin{array}{l}\mathrm{X} 22 \text { I did not realize that the } \\
\text { current type of travel is not } \\
\text { sustainable }\end{array}$ & & 3.82 & 0.96 & -0.56 & 0.044 \\
\hline \multirow{6}{*}{$\begin{array}{l}\text { Psychological } \\
\text { transformation } \\
\text { costs and fixed } \\
\text { consumption }\end{array}$} & $\begin{array}{l}\mathrm{X} 23 \text { It is difficult for me to change } \\
\text { my travel behavior and ways }\end{array}$ & & 2.99 & 1.08 & 0.222 & -0.703 \\
\hline & $\begin{array}{l}\text { X24 I do not think green tourism } \\
\text { can save money }\end{array}$ & & 2.78 & 1.25 & 0.309 & -0.942 \\
\hline & $\begin{array}{l}X 25 \text { I think green tourism } \\
\text { consumption will cause trouble and } \\
\text { inconvenience }\end{array}$ & & 2.84 & 1.09 & 0.309 & -0.731 \\
\hline & $\begin{array}{l}X 26 \text { I think green tourism will } \\
\text { reduce the comfort of travel }\end{array}$ & & 2.87 & 1.21 & 0.314 & -0.847 \\
\hline & $\begin{array}{l}X 27 \text { I think green tourism will meet } \\
\text { with resistance from fellow } \\
\text { travelers }\end{array}$ & & 2.69 & 1.11 & 0.404 & -0.663 \\
\hline & $\begin{array}{l}X 28 \text { I do not think green tourism } \\
\text { will be respected or appreciated }\end{array}$ & & 2.67 & 1.22 & 0.256 & -1.042 \\
\hline
\end{tabular}

Therefore, H1 and $\mathrm{H} 2$ are supported, while H3 was not. The perception of crisis and safety risk had a significant positive affect on the substitution of tourism consumption willingness (score $=0.355, \mathrm{t}=3.4, \mathrm{p}<0.001$ ), so hypothesis H4 is supported. The willingness to engage in sustainable consumption behavior had a significant positive affect on the substitution of tourism consumption willingness (score $=0.494, \mathrm{t}=4.8, \mathrm{p}<0.001$ ), so hypothesis H5 is supported. However, the psychological transformation cost and the fixed consumption habit had no significant influence on the willingness to replace tourism with consumption (ie, score $=0.021, \mathrm{t}=0.3, \mathrm{p}>0.5$ ), so hypothesis $\mathrm{H} 6$ is not supported.
Because there are two parallel mediating variables in this model, to verify their reliability, the indirect effect size of the two mediating routes was tested using the bootstrap method. The test data are presented in Table 9. The results show that $\mathrm{P}<0.01$, indirect effect size $>0.01$, and there is a significant mediating effect.

\section{Conclusions}

\section{Conclusions and Discussion}

Through a mixture of qualitative research based on grounded theory and quantitative model verification, this study explores the willingness of tourists to engage in sustainable 
Table 6 Reliability and Validity Tests of the Measurement Model

\begin{tabular}{|c|c|c|c|c|}
\hline Variable Options & & 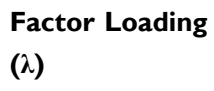 & $\begin{array}{l}\text { Composite Reliability } \\
\text { (CR) }\end{array}$ & $\begin{array}{l}\text { Mean Variance Extraction Value } \\
\text { (AVE) }\end{array}$ \\
\hline $\begin{array}{l}\text { Substitution of tourism consumption } \\
\text { willingness }\end{array}$ & $\begin{array}{l}Y 1 \\
Y 2 \\
Y 3 \\
Y 4 \\
Y 5 \\
Y 6\end{array}$ & $\begin{array}{l}0.741 \\
0.718 \\
0.607 \\
0.626 \\
0.771 \\
0.826\end{array}$ & 0.517 & 0.864 \\
\hline Sustainable consumption behavior & $\begin{array}{l}X 1 \\
X 2 \\
X 3 \\
X 4 \\
X 5 \\
X 6 \\
X 7 \\
X 8\end{array}$ & $\begin{array}{l}0.667 \\
0.788 \\
0.621 \\
0.626 \\
0.716 \\
0.765 \\
0.816 \\
0.724\end{array}$ & 0.516 & 0.894 \\
\hline Unusual environment & $\begin{array}{l}\times 9 \\
\times 10 \\
\times 11 \\
X 12 \\
X 13 \\
X 14 \\
X 15\end{array}$ & $\begin{array}{l}0.696 \\
0.741 \\
0.803 \\
0.846 \\
0.727 \\
0.792 \\
0.784\end{array}$ & 0.595 & 0.911 \\
\hline Crisis and security risk perception & $\begin{array}{l}\times 16 \\
\times 17 \\
\times 18 \\
\times 19\end{array}$ & $\begin{array}{l}0.615 \\
0.714 \\
0.767 \\
0.761\end{array}$ & 0.523 & 0.884 \\
\hline
\end{tabular}

Table 7 Correlation Coefficient Matrix Between Variables

\begin{tabular}{|c|c|c|c|c|c|}
\hline & $\begin{array}{l}\text { Substitution of } \\
\text { Tourism } \\
\text { Consumption } \\
\text { Willingness }\end{array}$ & $\begin{array}{l}\text { Sustainable } \\
\text { Consumption } \\
\text { Behavior }\end{array}$ & $\begin{array}{l}\text { Unusual } \\
\text { Environment }\end{array}$ & $\begin{array}{l}\text { Crisis and } \\
\text { Security Risk } \\
\text { Perception }\end{array}$ & $\begin{array}{l}\text { Psychological } \\
\text { Transformation Costs and } \\
\text { Fixed Consumption }\end{array}$ \\
\hline $\begin{array}{l}\text { Substitution of tourism } \\
\text { consumption willingness }\end{array}$ & 0.747 & & & & \\
\hline $\begin{array}{l}\text { Sustainable consumption } \\
\text { behavior }\end{array}$ & 0.678 & 0.799 & & & \\
\hline Unusual environment & 0.290 & 0.253 & 0.830 & & \\
\hline $\begin{array}{l}\text { Crisis and security risk } \\
\text { perception }\end{array}$ & 0.746 & 0.729 & 0.405 & $0.78 I$ & \\
\hline $\begin{array}{l}\text { Psychological } \\
\text { transformation costs and } \\
\text { fixed consumption }\end{array}$ & 0.086 & 0.035 & 0.564 & 0.124 & 0.792 \\
\hline
\end{tabular}

Note: The value on the diagonal of the matrix is the square root of the average variance extract. 


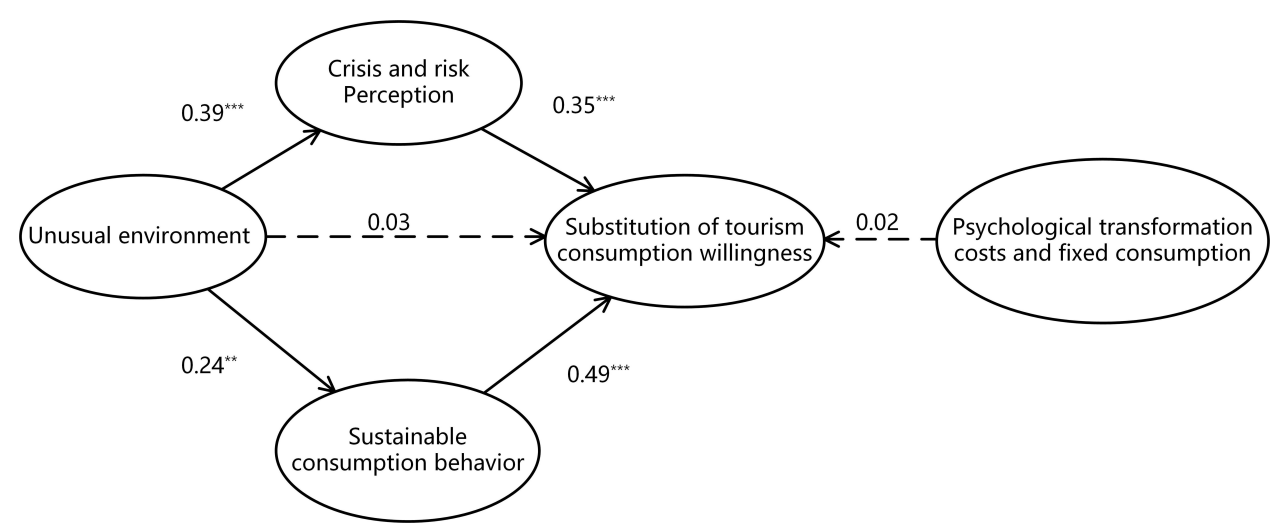

Figure 4 Analysis results of the influence path of the structural model.

Note: $(\mathrm{I})$ ** represents the $\mathrm{P}$ value less than $0.0 \mathrm{I}$ for significance level $(\mathrm{P}<0.0 \mathrm{I})$, and $* * *$ represents the $\mathrm{P}$ value less than $0.00 \mathrm{I}$ for significance level $(\mathrm{P}<0.00 \mathrm{I})$. $(2)$ solid line arrow indicates that the influence path is established, dotted line arrow indicates that the influence path is not established.

consumption behavior in an unusual environment and the substitution of tourism consumption willingness. ${ }^{50,51}$ The results show that, first, being in an unusual environment has a positive relationship with tourists' perceptions of crisis and safety risk. ${ }^{52}$ Tourists can consume instead of going through problem identification, cognition, and the prediction of an unusual environment. ${ }^{53,54}$ Being in an unusual environment will prompt tourists to review their knowledge and attitudes toward sustainable consumption and construct and strengthen values for sustainable consumption by themselves. ${ }^{55-59}$ Crisis and safety risk perceptions are positively correlated with the substitution of tourism consumption willingness. ${ }^{60,61}$ Tourists can identify the crisis and safety risks and make decisions on their own crisis interests to enhance the substitution of tourism consumption willingness to reduce travel. However, willingness to engage in sustainable consumption behavior is positively correlated with the substitution of willingness to consume tourism. The values of sustainable consumption held by tourists will promote changes in tourists' own consumption mode and will be influenced by social norms, promoting willingness to replace tourism with consumption. ${ }^{62,63}$

Second, as an intervening variable, crisis and safety risk awareness has a significant effect on sustainable consumption behavior, as strangeness in the usual environment will increase tourists' perception of risk and strengthen their willingness to consume as an alternative to tourism. Therefore, crisis and safety risk perception positively regulate the relationship between the environment and consumption behavior to engage in the substitution of tourism consumption willingness. ${ }^{64}$ As for the mediating variable of willingness to engage in

Table 8 Results of the Hypothesis Test: Direct Action

\begin{tabular}{|c|c|c|c|c|c|c|c|}
\hline $\begin{array}{l}\text { Model } \\
\text { Hypothesis }\end{array}$ & & & & $\boldsymbol{\beta}$ & CR & $\mathbf{P}$ & Result \\
\hline $\mathrm{HI}$ & Crisis and security risk perception & $<-$ & Unusual environment & 0.392 & 4.434 & $* * *$ & Support \\
\hline $\mathrm{H} 2$ & Sustainable consumption behavior & $<-$ & Unusual environment & 0.243 & 2.982 & 0.003 & Support \\
\hline $\mathrm{H} 3$ & $\begin{array}{l}\text { Substitution of tourism consumption } \\
\text { willingness }\end{array}$ & $<-$ & Unusual environment & 0.028 & 0.364 & 0.716 & $\begin{array}{l}\text { Not } \\
\text { support }\end{array}$ \\
\hline $\mathrm{H} 4$ & $\begin{array}{l}\text { Substitution of tourism consumption } \\
\text { willingness }\end{array}$ & $<-$ & Crisis and security risk perception & 0.355 & 3.356 & $* * *$ & Support \\
\hline H5 & $\begin{array}{l}\text { Substitution of tourism consumption } \\
\text { willingness }\end{array}$ & $<-$ & Sustainable consumption behavior & 0.494 & 4.843 & $* * *$ & Support \\
\hline $\mathrm{H} 6$ & $\begin{array}{l}\text { Substitution of tourism consumption } \\
\text { willingness }\end{array}$ & $<-$ & $\begin{array}{l}\text { Psychological transformation costs and fixed } \\
\text { consumption }\end{array}$ & 0.021 & 0.307 & 0.759 & $\begin{array}{c}\text { Not } \\
\text { support }\end{array}$ \\
\hline
\end{tabular}

Notes: $(\mathrm{I})$ **** represents the $\mathrm{P}$ value less than $0.00 \mathrm{I}$ for significance level $(\mathrm{P}<0.00 \mathrm{I})$. (2) solid line arrow indicates that the influence path is established, dotted line arrow indicates that the influence path is not established. 
Table 9 Results of Hypothesis Testing Mediation

\begin{tabular}{|c|c|c|c|c|c|c|c|c|}
\hline $\begin{array}{l}\text { Model } \\
\text { Hypothesis }\end{array}$ & & & & $\begin{array}{l}\text { Indirect } \\
\text { Effect }\end{array}$ & BootMean & BootSE & $\mathbf{P}$ & Result \\
\hline $\mathrm{H} 7$ & $\begin{array}{l}\text { Substitution of tourism } \\
\text { consumption willingness }\end{array}$ & $\begin{array}{l}\text { Crisis and security } \\
\text { risk perception }\end{array}$ & $\begin{array}{l}\text { Unusual } \\
\text { environment }\end{array}$ & 0.106 & 0.104 & 0.051 & 0.002 & Support \\
\hline $\mathrm{H} 8$ & $\begin{array}{l}\text { Substitution of tourism } \\
\text { consumption willingness }\end{array}$ & $\begin{array}{l}\text { Sustainable } \\
\text { consumption } \\
\text { behavior }\end{array}$ & $\begin{array}{l}\text { Unusual } \\
\text { environment }\end{array}$ & 0.091 & 0.087 & 0.042 & 0.009 & Support \\
\hline
\end{tabular}

sustainable consumption behavior, this can also positively adjust the relationship between the unusual environment and the substitution of tourism consumption willingness. In an unusual environment, tourists' ecological and sustainable tourism values are easy to awaken, and the substitution of tourism consumption willingness will be significantly enhanced. ${ }^{65}$

Third, as the mooring effect in PPM model theory has not been confirmed, the psychological transformation costs and fixed consumption of tourists are mainly affected by mindset and tourists' own interest decision-making, but the correlation between them and the substitution of tourism consumption willingness has not been confirmed. ${ }^{66,67}$ The unusual environment directly acting on the substitution of tourism consumption willingness has not been confirmed. The study found that an unusual environment plays a correlating role with two mediating variables, namely, the perception of risks to safety and sustainable consumption behavior, through a crisis.

The theoretical contribution of this study is mainly reflected in two aspects: First, it introduces a new environmental variable and uses this variable as the core to build an understanding of the substitution of tourism consumption willingness. This theoretical structural model and the use of the two mediating variables in moderator variable correlation functions extends and expands the current academic focus on the single perspective of the usual environment and may be conducive to the further study of the usual environment as a variable in tourists' travel behavior and experiences. However, tourists' psychological and situational environmental variables are introduced for the first time, expanding, and enriching the situational and empirical research on sustainable consumption behavior.

In the process of planning and development of tourist attractions, the government should pay attention to the "push" effect under an unusual environment to create a familiar and safe tourism environment for tourists, design suitable instructions, and create guidelines to form rich and varied publicity channels to promote the generation of sustainable tourism under unusual environment. Tourism enterprises should reduce redundant facilities and high-energy tourist items in the process of developing tourist attractions. The generation of sustainable tourism behavior requires tourists to integrate their own accurate identification under unusual environments, establish the mentality of safety risk cognition, and replace tourism behavior that may have an impact on the ecological environment with sustainable tourism consumption behavior.

\section{Limitations}

As related studies have found, tourism is a low-frequency activity that has different rates of consumption and frequency of revisiting. ${ }^{68}$ The apparent time-limited characteristic of tourism activity may dampen tourists' enthusiasm toward the idea of sustainable consumption and, from the usual environment to the usual circumstances, not only is the change geographical but tourists' individual behavior patterns and psychology also change.${ }^{69,70}$ In a heterogeneous environment, tourists' personal sustainable consumption behavior pattern will also change. Since this is a dynamic game process, it is also one of the research limitations of this study; one of its hidden assumptions is that it treats the willingness of tourists to engage in sustainable consumption and sustainable consumption behavior as inevitable, while in fact, there is a large gap between tourists' willingness and their actual behavior. Although tourists may engage in sustainable consumption in different environments and situations, this does not necessarily represent a full implementation. The relevant laws and ways to positively motivate sustainable consumption in tourists also need to be further examined through in-depth studies. Although the willingness to engage in sustainable consumption and consumer behavior has been the subject of a great deal of research, ${ }^{70-72}$ there is still need for further study of the effect of being in a heterogeneous environment similar to the usual environment. In addition, dynamic game research on tourists' 
sustainable consumption behavior in unusual environments also needs to be further discussed.

\section{Ethics Statement}

We declare that participants in our research study allow us to use their data for academic research and publication. All the participants were anonymous and their data was protected. All participants provided informed consent and this study was conducted in accordance with the Declaration of Helsinki. All the programs in our research study were approved by the Institutional Review Board of Zhejiang University of Finance and Economics.

\section{Funding}

This research is supported by the Philosophy and Social Science Foundation of Zhejiang Province (21NDJC083YB), National Natural Science Foundation of China (71702164), Natural Science Foundation of Zhejiang Province (LY20G010001). Soft Science Research Program of Science and Technology Department of Zhejiang, China (2021C35059), Philosophy and Social Science Planning Special Project of Zhejiang Province (20GXSZ26YB).

\section{Disclosure}

The authors declare that they have no conflicts of interest for this work.

\section{References}

1. Zhang L. Unusual environments: re-study of core concepts of tourism - an attempt to construct a framework for tourism studies. Tourism Tribune. 2009; 7:13-18.

2. Rogers J. Crossing an Administrative Boundary: A New Approach to Leaving the Usual Domestic Environment. Madrid: World Trade Organization; 2002.

3. De San Eugenio Vela J, Nogué J, Govers R. Visual landscape as a key element of place branding. J Place Manag Dev. 2008;1:23-44.

4. Guan J, Dong X, Bao B. Unusual environments and their influence on tourists' behavior. Tourism Tribune. 2018;260:28-36.

5. Belk RW. Collecting as luxury consumption: effects on individuals and households. J Econ Psychol. 1995;16:477-490. doi:10.1016/ 0167-4870(95)98956-X

6. McKercher B. Segment transformation in urban tourism. Tourism Manag. 2008;29:1215-1225. doi:10.1016/j.tourman.2008.03.005

7. Beales H, Mazis MB, Salop SC, Staelin R. Consumer search and public policy. J Con Res. 1981;8:11-22. doi:10.1086/208836

8. Gursoy D, Kim K, Uysal M. Perceived impacts of festivals and special events by organizers: an extension and validation. Tourism Manag. 2004;25:171-181. doi:10.1016/S0261-5177(03)00092-X

9. Lu ACC, Gursoy D. A conceptual model of consumers' online tourism confusion. Int J Contemp Hosp Manag. 2015;27:13201342. doi:10.1108/IJCHM-04-2014-0171

10. Crompton JL. An assessment of the image of Mexico as a vacation destination and the influence of geographical location upon that image. J Travel Res. 1979;17:18-23. doi:10.1177/0047287579 01700404
11. Shenkar O. Cultural distance revisited: towards a more rigorous conceptualization and measurement of cultural differences. $J$ Int Bus Stud. 2001;32:519-535. doi:10.1057/palgrave.jibs.8490982

12. Ye BH, Zhang HQ, Yuen PP. Cultural conflicts or cultural cushion? Ann Tourism Res. 2013;43:321-349. doi:10.1016/j. annals.2013.07.003

13. Cohen J. Comment: the corporate dividend-saving decision. J Financ Quant Anal. 1972;7:1549-1554. doi:10.2307/2329934

14. Mitchell VW, Greatorex M. Consumer purchasing in foreign countries: a perceived risk perspective. Int $J$ Adv. 1993;9:295-307. doi:10.1080/02650487.1990.11107160

15. Chen H. Unusual environments and experiences of them: a reexploration of the core concept of tourism. Tourism Tribune. 2017;32:22-31.

16. Hares A, Dickinson J, Wilkes K. Climate change and the air travel decisions of UK tourists. J Transp Geogr. 2010;18(3):466-473. doi:10.1016/j.jtrangeo.2009.06.018

17. Benner M. Overcoming overtourism in Europe: towards an institutional-behavioral research agenda. Zeitschrift für Wirtschafts Geographie. 2019. doi:10.1515/zfw-2019-0016

18. Juvan E, Dolnicar S. The attitude-behaviour gap in sustainable tourism. Ann Tourism Res. 2014;48:76-95. doi:10.1016/j. annals.2014.05.012

19. Juvan E, Dolnicar S. Drivers of pro-environmental tourist behaviours are not universal. J Cleaner Prod. 2017;166:879-890. doi:10.1016/j. jclepro.2017.08.087

20. Lao K. Research on mechanism of consumer innovativeness influencing Sustainable consumption behavior. Nankai Bus Rev. 2014;5:211-224. doi:10.1108/NBRI-11-2013-0041

21. Lu LC, Chang HH, Chang A. Consumer personality and green buying intention: the mediate role of consumer ethical beliefs. J Bus Eth. 2015;127:205-219. doi:10.1007/s10551-013-2024-4

22. Pinto DC, Nique WM, Herter MM, Borges A. Sustainable consumers and their identities: how identities change the motivation for Sustainable consumption. Int J Con Stud. 2016;40:742-753. doi:10.1111/ijcs. 12282

23. Nguyen HV, Nguyen CH, Hoang TTB. Sustainable consumption: closing the intention-behavior gap. Sustain Dev. 2018;27:118-129. doi:10.1002/sd.1875

24. Porter ME. Technology and competitive advantage. J Bus Strategy. 1985;5:60-78. doi:10.1108/eb039075

25. Reinartz W, Thomas JS, Kumar V. Balancing acquisition and retention resources to maximize customer profitability. $J$ Mark. 2005;69:63-79. doi:10.1509/jmkg.69.1.63.55511

26. Ratneshwar S, Barsalou LW, Pechmann C, Moore PM. Goal-derived categories: the role of personal and situational goals in category representations. J Con Psychol. 2001;10:147-157. doi:10.1207/ s15327663jcp1003_3

27. Heberle R. The causes of rural-urban migration: a survey of German theories. Am J Sociol. 1938;43:932-950. doi:10.1086/217875

28. Moon B. Paradigms in migration research: exploring 'moorings' as a schema. Prog Hum Geogr. 1995;19:504-524. doi:10.1177/ 030913259501900404

29. Goossens C. Tourism information and pleasure motivation. Ann Tourism Res. 2000;27:301-321. doi:10.1016/S0160-7383(99)00067-5

30. Kim SS, Lee CK, Klenosky DB. The influence of push and pull factors at Korean national parks. Tourism Manag. 2003;24:169-180. doi:10.1016/S0261-5177(02)00059-6

31. Klenosky BD. The "pull" of tourism destinations: a means-end investigation. J Travel Res. 2002;40:396-403. doi:10.1177/ 004728750204000405

32. Jung J, Han H, Oh M. Travelers' switching behavior in the airline industry from the perspective of the push-pull-mooring framework. Tourism Manag. 2017;59:139-153. doi:10.1016/j.tourman.2016.07.018

33. Ajzen I. The theory of planned behavior. Org Behav Hum Decis Proc. 1991;50:179-211. doi:10.1016/0749-5978(91)90020-T 
34. Godin G, Valois P, Lepage L, Desharnais R. Predictors of smoking behaviour: an application of ajzen's theory of planned behaviour. Addiction. 2010;87(9):1335-1343. doi:10.1111/j.1360-0443.1992. tb02742.x

35. Stern PC, Dietz T, Abel T, Guagnano GA, Kalof L. A value-beliefnorm theory of support for social movements: the case of environmentalism. Hum Ecol Rev. 1999;6:81-97.

36. Stern PC. New environmental theories: toward a coherent theory of environmentally significant behavior. J Soc Issues. 2000;56:407-424. doi:10.1111/0022-4537.00175

37. Dunlap RE, Liere KDV, Mertig AG, Jones RE. New trends in measuring environmental attitudes: measuring endorsement of the new ecological paradigm: a revised NEP scale. J Soc Issues. 2000;56(3):425-442. doi:10.1111/0022-4537.00176

38. Gensler S, Leeflang P, Skiera B. Impact of online channel use on customer revenues and costs to serve: considering product portfolios and self-selection. Int J Res Mark. 2012;29:192-201. doi:10.1016/j. ijresmar.2011.09.004

39. Davis FD, Venkatesh V. A critical assessment of potential measurement biases in the technology acceptance model: three experiments. Int J Hum Comput Stud. 1996;45:19-45. doi:10.1006/ijhc.1996.0040

40. Straub D, Keil M, Brenner W. Testing the technology acceptance model across cultures: a three country study. Inf Manag. 1997;33:111. doi:10.1016/S0378-7206(97)00026-8

41. Chen T, Shi J, Yang J, Li G. Enhancing network cluster synchronization capability based on artificial immune algorithm. Hum Cent Comput Inf Sci. 2019;9:3. doi:10.1186/s13673-019-0164-y

42. Li M, Cai LA, Lehto XY, Huang J. A missing link in understanding revisit intention - the role of motivation and image. $J$ Travel Tourism Mark. 2010;27:335-348. doi:10.1080/10548408.2010.481559

43. Cai LA, Li M. Distance-segmented rural tourists. J Travel Tourism Mark. 2019;26:751-761. doi:10.1080/10548400903356137

44. Kauffman RJ, Wang B. Tuning into the digital channel: evaluating business model characteristics for internet firm survival. Inf Tech Manag. 2008;9:215-232. doi:10.1007/s10799-008-0040-3

45. Penz E, Hogg MK. The role of mixed emotions in consumer behaviour: investigating ambivalence in consumers' experiences of approach-avoidance conflicts in online and offline settings. Eur $J$ Mark. 2011;45:104-132. doi:10.1108/03090561111095612

46. Chiu H, Hsieh Y, Roan J, Tseng KJ, Hsieh JK. The challenge for multichannel services: cross-channel free-riding behavior. Electron Com Res Appl. 2011;10:268-277. doi:10.1016/j.elerap.2010.07.002

47. Ansari A, Mela CF, Neslin SA. Customer channel migration. J Mark Res. 2008;45:60-76. doi:10.1509/jmkr.45.1.60

48. Van Trijp HCM, Hoyer WD, Inman JJ. Why Switch? Product Category-Level Explanations for True Variety-Seeking Behavior. J Mark Res. 1996;33:281-292.

49. Polites GL, Karahanna E. Shackled to the status quo: the inhibiting effects of incumbent system habit, switching costs, and inertia on new system acceptance. MIS Q. 2012;36:21-42. doi:10.2307/ 41410404

50. Thomas JS, Sullivan UY. Managing marketing communications with multichannel customers. J Mark. 2015;69:239-251. doi:10.1509/ jmkg.2005.69.4.239

51. Cho J. Likelihood to abort an online transaction: influences from cognitive evaluations, attitudes, and behavioral variables. Inf Manag. 2004;41:827-838. doi:10.1016/j.im.2003.08.013

52. Bansal HS, Taylor SF. Investigating interactive effects in the theory of planned behavior in a service-provider switching context. Psychol Mark. 2002;19:407-425. doi:10.1002/mar.10017

53. Bagozzi RP, Warshaw PR. An examination of the etiology of the attitude-behavior relation for goal-directed behavior. Multivariate Behav Res. 1992;27:601-634. doi:10.1207/s15327906mbr2704_6
54. Zamfir A, Corbos RA. Towards sustainable tourism development in urban areas: case study on Bucharest as tourist destination. Sustainability. 2015;7:12709-12722. doi:10.3390/su70912709

55. Iunius R, Cismaru L, Foris D. Raising competitiveness for tourist destinations through information technologies within the newest tourism action framework proposed by the European Commission. Sustainability. 2015;7:12891-12909. doi:10.3390/su70912891

56. Jaafar M, Nordin AOS, Marzuki A, Abdullah S. Development of ecotourism products in Kilim Geopark based on tourist perceptions. $J$ Sustainability Sci Manag. 2015;10:1-18.

57. Yi-Min L. Effects of story marketing and travel involvement on tourist behavioral intention in the tourism industry. Sustainability. 2014;6:9387-9397. doi:10.3390/su6129387

58. Gianna M, Laurie M. There is no such thing as sustainable tourism: re-conceptualizing tourism as a tool for sustainability. Sustainability. 2014;6:2538-2561. doi:10.3390/su6052538

59. Lucas GR, Manuel RP, Xiaosheng Y. From farm to rural hostel: new opportunities and challenges associated with tourism expansion in Daxi, a village in Anji County, Zhejiang, China. Sustainability. 2011;3:306-321. doi:10.3390/su3010306

60. Barr S, Shaw G, Coles T, Prillwitz J. 'A holiday is a holiday': practicing sustainability, home and away. J Transp Geogr. 2010;18 (3):0-481. doi:10.1016/j.jtrangeo.2009.08.007

61. Han H, Hsu LT, Sheu C. Application of the theory of planned behavior to sustainable hotel choice: testing the effect of environmental friendly activities. Tourism Manag. 2011;30:325-334.

62. Duerden MD, Witt PA. The impact of direct and indirect experiences on the development of environmental knowledge, attitudes, and behavior. J Environ Psychol. 2010;30:379-392. doi:10.1016/j. jenvp.2010.03.007

63. Von Borgstede C, Andersson M, Johnsson F. Public attitudes to climate change and carbon mitigation-implications for energy-associated behaviours. Energy Policy. 2013;57:182-193. doi:10.1016/j. enpol.2013.01.051

64. Pagiaslis A, Krontalis AK. Green consumption behavior antecedents: environmental concern, knowledge, and beliefs. Psychol Mark. 2014;31:335-348. doi:10.1002/mar.20698

65. Elias W, Shiftan Y. The influence of individual's risk perception and attitudes on travel behavior. Transp Res A. 2012;46:1241-1251.

66. Gilg A, Barr S, Ford N. Sustainable consumption or sustainable lifestyles? Identifying the sustainable consumer. Futures. 2005;37:0-504. doi:10.1016/j.futures.2004.10.016

67. Perera C, Auger P, Klein J. Sustainable consumption practices among young environmentalists: a practice theory perspective. J Bus Eth. 2016;152:843-864. doi:10.1007/s10551-016-3376-3

68. Jo M, Shin J. Market strategy for promoting green consumption: consumer preference and policy implications for laundry detergent. Int J Con Stud. 2017;41:283-290. doi:10.1111/ijcs. 12339

69. Chonghuan X. A big-data oriented recommendation method based on multi-objective optimization. Knowl Based Syst. 2019;177:11-21. doi:10.1016/j.knosys.2019.03.032

70. Wang J, Chonghuan X, Liu W. Understanding the adoption of mobile social payment?From the cognitive behavioral perspective. Int $J$ Mobile Commun. 2022. doi:10.1504/IJMC.2022.10036150

71. Chonghuan X. A novel recommendation method based on social network using matrix factorization technique. Inf Process Manag. 2018;54(3):463-474. doi:10.1016/j.ipm.2018.02.005

72. Jiang C, Li R, Chen T, Xu C, Li L, Li S. A two-lane mixed traffic flow model with drivers' intention to change lane based on cellular automata. Int J Bio Inspired Comput. 2020;6(4):229-240. doi:10.1504/IJBIC.2020.112328 


\section{Publish your work in this journal}

Psychology Research and Behavior Management is an international, peer-reviewed, open access journal focusing on the science of psychology and its application in behavior management to develop improved outcomes in the clinical, educational, sports and business arenas. Specific topics covered in the journal include: Neuroscience, memory and decision making; Behavior modification and management; Clinical applications; Business and sports performance management; Social and developmental studies; Animal studies. The manuscript management system is completely online and includes a very quick and fair peer-review system, which is all easy to use. Visit http://www. dovepress.com/testimonials.php to read real quotes from published authors. 